\section{Quantitative assessment of arginine methylation in free versus protein-incorporated amino acids in vitro and in vivo using protein hydrolysis and high-performance liquid chromatography}

\author{
Patrick Bulau, Dariusz Zakrzewicz, Kamila Kitowska, Birgit Wardega, \\ Joachim Kreuder, and Oliver Eickelberg \\ University of Giessen School of Medicine, Giessen, Germany
}

BioTechniques 40:305-310(March 2006)

doi $10.2144 / 000112081$

\begin{abstract}
Arginine methylation constitutes a posttranslational modification dependent on the action of protein arginine methyltransferases (PRMTs). Using S-adenosylmethionine as a methyl donor, PRMTs catalyze the formation of monomethylarginine (L-NMMA), asymmetric dimethylarginine (ADMA), or symmetric dimethylarginine (SDMA). Protein arginine methylation is involved in the regulation of signal transduction, RNA export, and cell proliferation, but a quantitative view of arginine methylation of the cell and tissue proteome remains to be performed. In this study, we developed a high-performance liquid chromatography (HPLC)based method to accurately quantify methylated arginines in free and protein-incorporated amino acid pools of cell and tissue extracts, using protein precipitation and hydrolysis, $H P L C$ separation, and fluorescence detection for the simultaneous quantification of $L$-arginine (L-Arg), L-NMMA, ADMA, and SDMA. This method permits accurate assessment of the degree of protein arginine methylation in complex biological samples. Using this method, we determined dynamic changes in protein methylation in vitro in cells subjected to proteasome inhibition. We furthermore demonstrate differential methylation patterns in heart and kidney lysates in vivo. Thus, the described method will greatly facilitate our understanding of the role of arginine methylation in physiology and pathophysiology and of the effects of pharmacological interventions on arginine methylation in select cell culture models.
\end{abstract}

\section{INTRODUCTION}

Asymmetric dimethylarginine (ADMA) is a naturally occurring amino acid that was originally identified in plasma and urine (1-3). ADMA is a competitive inhibitor of all nitric oxide synthase (NOS) isoforms and thus modulates the biological effects of NO, especially in the cardiovascular system $(1,4)$. Several studies have suggested that ADMA plasma levels constitute a marker of endothelial dysfunction and cardiovascular disease (5-7).

Three main forms of methylarginine have been identified in eukaryotes as $\mathrm{N}^{\mathrm{G}}$-monomethylarginine (L-NMMA), $\mathrm{N}^{\mathrm{G}} \mathrm{N}^{\mathrm{G}}$ (asymmetric) dimethylarginine (ADMA), and $\mathrm{N}^{\mathrm{G}} \mathrm{N}^{\prime} \mathrm{G}$ (symmetric) dimethylarginine (SDMA), all characterized by methylation of one or both guanidine nitrogen atoms of arginine. Methylarginines are generated by the action of protein arginine methyltransferases (PRMTs), which utilize S-adenosylmethionine (AdoMet) as a methyl donor $(8,9)$. Type I PRMTs catalyze ADMA formation in select target proteins, whereas type II PRMTs catalyze SDMA formation through methylation of both guanidino nitrogens. In addition, all PRMTs can also catalyze monomethylation, thereby leading to the formation of LNMMA $(8,9)$.

Up to now, the biological impact of protein arginine methylation remains to be fully elucidated, but this process is reported to be involved in the regulation of RNA binding, control of transcription, DNA repair, protein localization, protein-protein interaction, signal transduction, and recycling of receptors (9). Large-scale proteomic approaches have unraveled a potentially broad range of substrate proteins for PRMT methylation $(10,11)$, suggesting a significant role for arginine methylation in cellular processes. Moreover, increased methylation of cellular proteins by PRMTs may significantly contribute to the level of free methylarginines via protein degradation $(12,13)$, as direct methylation of free arginines has thus far not be demonstrated.

Sensitive and accurate quantification methods for $\mathrm{L}$-arginine (LArg), L-NMMA, ADMA, and SDMA involve ion-exchange extraction from plasma, urine, or cerebrospinal fluid, followed by high-performance liquid chromatography (HPLC) separation with fluorescence detection (14-20), although capillary electrophoresis $(1,21)$ and liquid chromatography/ mass spectrometry (LC/MS) have also been employed $(22,23)$. None of the reported methods, however, have ever been used for the quantification of the degree of protein arginine methylation in the proteome of biological samples. In the present study, an approach using protein precipitation and hydrolysis combined with HPLC separation and fluorescence detection for the simultaneous quantification of LArg, L-NMMA, ADMA, and SDMA in cellular and tissue proteins was developed. This method allowed us to calculate the degree of methylation of protein-incorporated and free arginines, demonstrating dynamic changes in arginine methylation in cellular lysates of proteasome-inhibited A549 cells in vitro, as well as differential arginine methylation patterns comparing mouse heart with kidney tissue extracts in vivo.

\section{MATERIALS AND METHODS}

\section{Materials and HPLC System}

L-Arg, L-NMMA, L-homoarginine, ADMA, SDMA, and myelin basic protein (MBP) from bovine brain were purchased from Sigma (St. Louis, MO, USA), while acetonitrile, methanol (both LiChrosolv), and concentrated $(25 \%, \mathrm{v} / \mathrm{v})$ ammonia were obtained from Merck (Darmstadt, Germany). Ortho-phthaldialdehyde (OPA) and borate buffer were purchased from Grom (Rottenburg-Hailfingen, Germany). Oasis ${ }^{\circledR}$ MCX cation-exchange 
solid phase extraction (SPE) columns (30 $\mathrm{mg}, 1 \mathrm{~mL}$ ) were supplied by Waters (Eschborn, Germany). All other chemicals were of analytical grade. Separation of amino acids was performed on a HPLC system consisting of an WISP 710B auto sampler, a model 6000 pump, a model 470 fluorescence detector (Waters) and a data acquisition system (Maxima 820, version 3.31; Millipore, Schwalbach, Germany).

\section{Sample Preparation and Protein Hydrolysis}

Mouse hearts and kidneys were surgically excised after thoracotomy, immediately homogenized in liquid nitrogen followed by addition of icecold cell lysis buffer [20 mM Tris-HCl, $\mathrm{pH}$ 7.5, $150 \mathrm{mM} \mathrm{NaCl}, 1 \mathrm{mM}$ EDTA, $1 \mathrm{mM}$ EGTA, $1 \%(\mathrm{v} / \mathrm{v})$ Triton $^{\circledR} \mathrm{X}-$ 100, $2 \mathrm{mM} \mathrm{Na} \mathrm{NO}_{4}$ ]. Homogenized tissue was incubated for $1 \mathrm{~h}$ on ice and centrifuged for $15 \mathrm{~min}$ at $16,000 \times \mathrm{g}$. The resulting supernatant was stored at $-20^{\circ} \mathrm{C}$. Proteins were then precipitated by mixing $100 \mu \mathrm{L}$ tissue/cell extracts with an equal volume of $20 \%$ (v/v) trichloroacetic acid for $20 \mathrm{~min}$. After centrifugation at $16,000 \times g$ for $12 \mathrm{~min}$, the supernatants were removed, and the protein pellets were washed with $100 \mu \mathrm{L}$ ice-cold acetone for $60 \mathrm{~min}$ at $-20^{\circ} \mathrm{C}$. The suspension was centrifuged at $16,000 \times g$ for $12 \mathrm{~min}$, and the resulting protein pellet was dissolved in $100 \mu \mathrm{L}$ distilled water. Precipitation of $\operatorname{MBP}(100 \mu \mathrm{L}$ of a $0.25 \mu \mathrm{g} / \mu \mathrm{L}$ solution $)$ was similarly performed prior to protein hydrolysis, SPE, derivatization, and chromatographic separation. Protein concentrations of crude extracts and precipitated proteins were determined by the Bio-Rad Protein Assay Dye Reagent Concentrate using a SmartSpec ${ }^{\mathrm{TM}} 3000$ spectrophotometer (Bio-Rad Laboratories, Hercules, California, USA). Prior to protein hydrolysis, $20 \mu \mathrm{L}$ of each sample were combined with $10 \mu \mathrm{L}$ L-homoarginine $(4 \mathrm{pmol} / \mu \mathrm{L})$ as an internal standard. Total hydrolysis of precipitated protein fractions was achieved by gas-phase hydrolysis with $6 \mathrm{M} \mathrm{HCl}$ (constant boiling, sequencing grade; Pierce, Bonn, Germany) at $110^{\circ} \mathrm{C}$ for $16 \mathrm{~h}$. Samples were dried by use of a vacuum centrifuge and stored at $-20^{\circ} \mathrm{C}$ until further analyzed.

\section{Cell Culture}

The human lung epithelial cell line A549 was obtained from the German Microbe and Cell Culture Collection (DSMZ, Braunschweig, Germany) and maintained at $37^{\circ} \mathrm{C}$ in Dulbecco's modified Eagle medium (DMEM)/F-12 medium containing $10 \%$ fetal bovine serum (both from Invitrogen, Karlsruhe, Germany). In experiments using the cell-permeable proteasome inhibitor aldehyde carbobenzoxy-L-leucyl-Lleucyl-L-leucinal (MG-132; Merck Biosciences, Bad Soden, Germany), the medium was supplemented with 5 $\mu \mathrm{M}$ MG-132 as well. Protein extracts were then prepared according to the procedure described above.

\section{Isolation of Basic Amino Acids and Derivatization}

Tissue/cell extracts and amino acid hydrolysates were subjected to crude fractionation on Oasis MCX cationexchange SPE columns. For tissue/cell extracts, $30 \mu \mathrm{L}$ of each sample were combined with $10 \mu \mathrm{L}$ L-homoarginine $(4 \mathrm{pmol} / \mu \mathrm{L})$ as an internal standard and adjusted to a final volume of $1 \mathrm{~mL}$ with phosphate-buffered saline (PBS; PAA Laboratories, Pasching, Austria). Amino acid hydrolysates were directly dissolved in $1 \mathrm{~mL}$ PBS. All conditioning, washing, and elution steps were performed on a vacuum-manifold with a capacity for 24 columns (Macherey-Nagel, Düren, Germany) at a flow rate of about $0.5 \mathrm{~mL} / \mathrm{min}$. The SPE columns were conditioned with $2 \mathrm{~mL}$ methanol/water/ammonia (50:45:5, v/v/v) followed by $2 \mathrm{~mL}$ PBS prior to sample application. Samples were passed through SPE cartridges, and the contaminating components were rinsed off with $2 \mathrm{~mL} 0.1 \mathrm{M} \mathrm{HCl}$ followed by $2 \mathrm{~mL}$ methanol. L-Arg, ADMA, and SDMA were eluted with 1 $\mathrm{mL}$ methanol/water/ammonia (50:45:5, $\mathrm{v} / \mathrm{v} / \mathrm{v})$. The samples were dried under nitrogen stream at $65^{\circ} \mathrm{C}$. Eluates were then redissolved in $230 \mu \mathrm{L}$ distilled water and centrifuged at $14,000 \times$ $g$ for 2 min to remove particulates prior to derivatization for HPLC. The OPA reagent was freshly prepared in potassium borate buffer (1 M, pH 10.7) according to the manufacturer's instructions. Samples $(115 \mu \mathrm{L})$ were combined with $50 \mu \mathrm{L}$ OPA reagent, immediately transferred to the autosampler, and injected exactly after $90 \mathrm{~s}$.

\section{Chromatographic Conditions}

Fluorescent amino acid derivatives were separated on a SunFire ${ }^{\mathrm{TM}}$ C18 column $(4.6 \times 150 \mathrm{~mm} ; 3.5 \mu \mathrm{m}$ particle size; $100 \AA$ pore size) with a $\mu$ Bondapak $^{\mathrm{TM}} \mathrm{C} 18$ guard column $(10 \mu \mathrm{M})$ at $30^{\circ} \mathrm{C}$ and a flow rate of $1.1 \mathrm{~mL} / \mathrm{min}$ (all columns were from Waters). After sample injection (125 $\mu \mathrm{L}$ ), separation was performed under isocratic conditions with $7.8 \%(\mathrm{v} / \mathrm{v})$ acetonitrile in $25 \mathrm{mM}$ potassium phosphate buffer ( $\mathrm{pH}$ 6.8) as solvent. The isocratic conditions were maintained for $48 \mathrm{~min}$. In order to elute strongly bound compounds, the column was flushed with acetonitrile/ water $(50: 50, \mathrm{v} / \mathrm{v})$ for $2 \mathrm{~min}$ and reequilibrated under isocratic conditions for $10 \mathrm{~min}$ prior to the next injection. Fluorescent derivatives were detected at excitation and emission wavelengths of 330 and $450 \mathrm{~nm}$, respectively. After elution of L-Arg (25 min), the gain of the detector was switched to a 100-fold higher sensitivity. Quantification was performed on the base of the peak area.

\section{Standard Curves, Recovery, and Statistical Analysis}

Standard solutions were prepared as described previously by Teerlink et al. (17). Calibration was performed using six combined standards spanning the range 1.5 to $450 \mathrm{pmol}(60 \mathrm{nM}$ to $18 \mu \mathrm{M})$ for L-Arg, 0.15 to $45 \mathrm{pmol}$ (6 $\mathrm{nM}$ to $1.8 \mu \mathrm{M}$ ) for L-NMMA and ADMA, and 0.09 pmol to 9 pmol (3.6 $\mathrm{nM}$ to $0.36 \mu \mathrm{M})$ for SDMA. Standard solutions were combined with 15 pmol of the internal standard L-homoarginine and subjected to SPE, derivatization, and chromatography as described above. Calibration curves were calculated by plotting the ratio of the peak area of analyte (L-Arg, L-NMMA, ADMA, or SDMA) to the area of the 
internal standard (L-homoarginine) versus analyte quantity. For determination of recovery, standard solutions (150 pmol L-Arg, 15 pmol L-NMMA, Lhomoarginine, and ADMA, and 3 pmol SDMA) were subjected to protein hydrolysis prior to SPE, derivatization, and chromatographic separation. Statistical analysis was performed using the Student's $t$-test.

\section{RESULTS AND DISCUSSION}

\section{Method Validation}

In the present study, a method for the simultaneous quantification of free and protein-incorporated L-Arg, L-NMMA, ADMA, and SDMA in cellular and tissue protein extracts was developed. The sensitive detection of free methylarginines in plasma, urine, or cerebrospinal fluid using SPE, OPA-derivatization, and reverse-phase HPLC (RP-HPLC) separation was initially introduced by Teerlink et al. (17) and has been repeatedly used in the measurement of methylarginines in liquid biological samples, such as mentioned above.

Whereas a recent study has also compared ADMA levels in cell lysates (24), the degree of arginine methylation (L-Arg, L-NMMA, ADMA, and SDMA) in the cellular proteome has not been quantified thus far. We therefore developed an assay for accurately quantifying the degree of arginine methylation in cell and tissue protein lysates. This method entails the isolation of cellular proteins by precipitation and hydrolysis, isolation/ purification of methylarginines by SPE, derivatization with OPA, and finally RP-HPLC separation with fluorescence detection.

In this study, the separation of methylarginines was performed on a SunFire C18 column under optimized isocratic conditions to enhance the resolving power. Using our modified

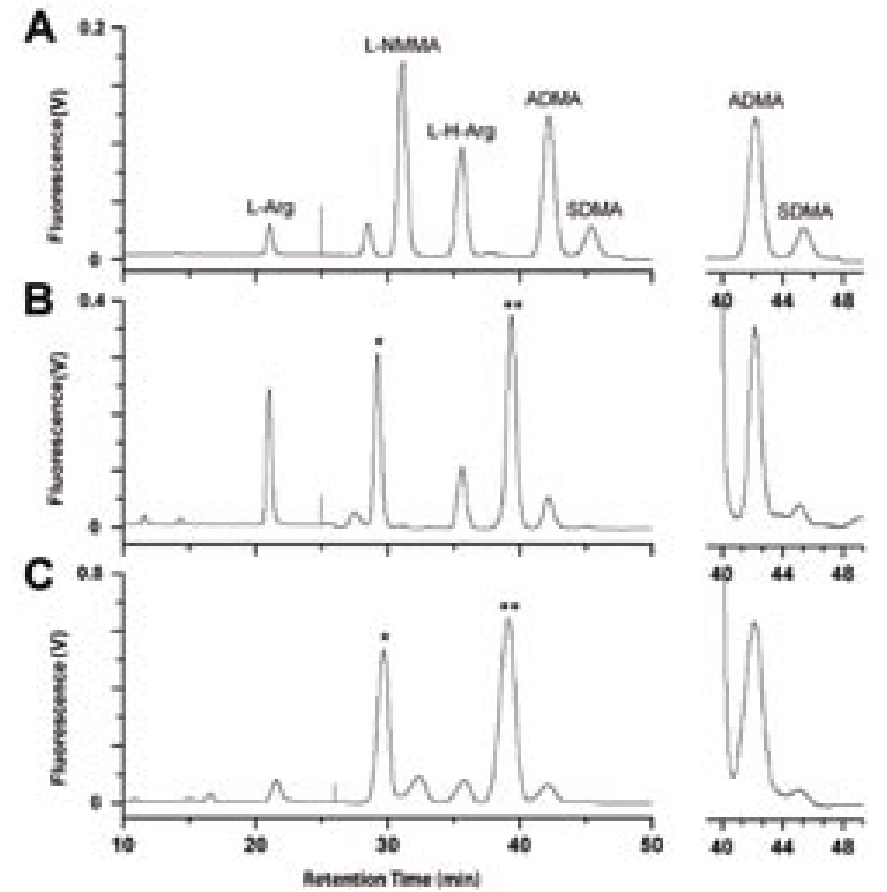

Figure 1. Quantification of methylarginine by high-performance liquid chromatography (HPLC). HPLC chromatograms of a combined standard containing $150 \mathrm{pmol} \mathrm{L}$-arginine (L-Arg), $15 \mathrm{pmol} \mathrm{N}^{\mathrm{G}}$-monomethylarginine (L-NMMA), L-homoarginine (L-H-Arg), $\mathrm{N}^{\mathrm{G}} \mathrm{N}^{\mathrm{G}}$ (asymmetric) dimethylarginine (ADMA), and 3 pmol $\mathrm{N}^{\mathrm{G}} \mathrm{N}^{\prime \mathrm{G}}$ (symmetric) dimethylarginine (SDMA) (A), amino acid hydrolysates from precipitated heart proteins (B), and free amino acids from crude heart extracts (C). Chromatographic conditions are described in detail in the Materials and Methods section. *, ortho-phthaldialdehyde (OPA) reagent; **, unidentified component. Inset: region 40-48 min, (B and C) magnified $5 \times$. setup, all forms of methylarginine and L-homoarginine are well-resolved in samples of free and protein-incorporated amino acids from mouse heart lysates (Figure 1). To confirm the identity of each individual peak, both crude tissue extracts and protein hydrolysates were spiked with L-Arg, ADMA, and SDMA. L-homoarginine was chosen as the internal standard over L-NMMA, as the peak area obtained for L-homoarginine in both free and incorporated amino acids could be disregarded $(<0.5 \%$ and not detectable, respectively).

\section{Recovery, Calibration, and Detection Limits}

Since our detection method relies on the quantification of methylated arginines after protein precipitation and acid hydrolysis, we validated this approach by assessing the amount of methylated arginines before and after protein hydrolysis using a standard solution of L-Arg, L-NMMA, Lhomoarginine, ADMA, and SDMA. Standards were subjected to protein hydrolysis, SPE, and chromatographic separation. For all components, the recovery rates were greater than $80 \%$ (L-Arg, $84.6 \% \pm 2.5 \%$; L-NMMA, $84.5 \% \pm 3.8 \%$; L-homoarginine, $87.5 \% \pm 4.4 \%$; ADMA, $88.1 \% \pm 4.1 \%$; SDMA, $87.8 \% \pm 5.0 \% ; n=6$ ). Using the calculated recovery of L-homoarginine as the internal standard, we determined the relative recovery for each component, which is defined as the single recovery divided by the value of the internal standard. The relative recoveries for all arginine forms were close to $100 \%$ (L-Arg, $96.8 \% \pm 2.6 \%$; L-NMMA, $96.6 \% \pm 2.6 \%$; ADMA, $100.7 \% \pm 1.8 \%$; SDMA, $100.4 \% \pm$ $2.6 \%$ ), demonstrating that the use of L-homoarginine as an internal standard ensures precision equal to that obtained with L-NMMA $(17,18)$. Similar to the recovery observed using the aforementioned standard solutions, the recovery of L-homoarginine from crude heart extract was $85 \% \pm 12 \%(n=6)$. Calibration curves obtained by plotting the ratio of the peak area of analyte to the area of the internal standard versus analyte quantity were all linear with correlation coefficients $>0.9999$. 


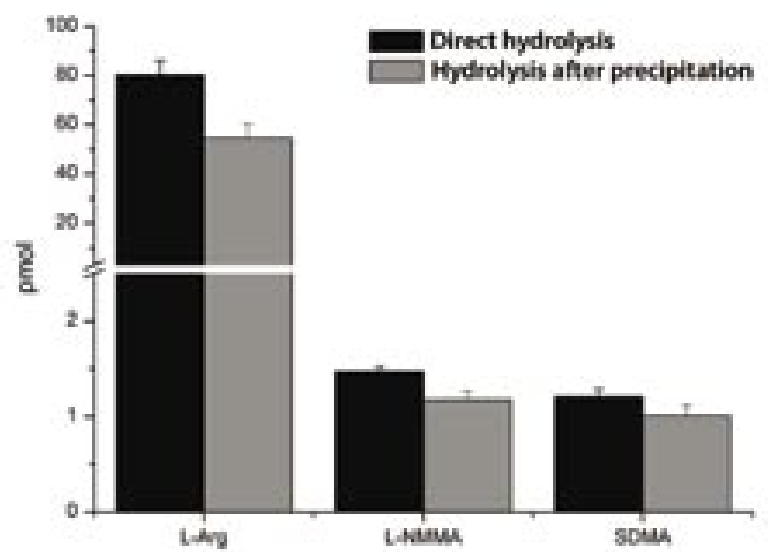

Figure 2. Protein precipitation does not selectively enrich/deplete protein methylation characteristics. $\mathrm{N}^{\mathrm{G}}$-monomethylarginine (LNMMA) and $\mathrm{N}^{\mathrm{G}} \mathrm{N}^{\prime \mathrm{G}}$ (symmetric) dimethylarginine (SDMA) content in amino acid hydrolysates of purified myelin basic protein from bovine brain is similar before and after precipitation. Arginine methylation was determined as described in myelin basic protein (MBP) amino acid hydrolysates without prior protein precipitation $(n=6$, black bars) and MBP amino acid hydrolysates after protein precipitation ( $n=6$, gray bars). Data are represented as mean \pm SD in pmol. L-Arg, L-arginine.
Using this assay, the detection limit for all arginine forms was approximately 100 fmol $(0.003 \mu \mathrm{M}$ in crude extract, based on a signal-to-noise ratio of 3 ), which is comparable with other HPLC methods with fluorescence detection $(17,18)$ and with LC/MS-based approaches (23).

\section{Quantification of Protein Arginine Methylation in A549 Cells Under Proteasome Inhibition}

To confirm that the protein precipitation procedure used here does not selectively arginines, we measured the extent of arginine methylation in a well-characterized purified protein, MBP. Figure 2 depicts the recovery of L-Arg, LNMMA, and SDMA in amino acid hydrolysates of MBP from bovine brain before and after protein precipitation. Around $2 \%$ of arginine residues in MBP were found to be monomethylated, while symmetric dimethylation occurred in approximately $1.5 \%$. Asymmetric dimethylation of arginine residues was not detected, which is in agreement with a previous study on the characterization of MBP methylation (25). As expected, no differences in the ratios of L-NMMA/L-Arg, SDMA/ L-Arg, or SDMA/L-NMMA were noted comparing the values obtained before and after protein precipitation. This indicated that our precipitation procedure did not selectively enrich or deplete specific mono- and/or symmetric dimethylated proteins, thus allowing accurate quantification of methylarginines in protein precipitates.

enrich or deplete specific (methylated)

Table 1. Comparison of the Degree of Arginine Methylation in A549 Cell Protein Hydrolysates and Their Respective Crude Extracts After Treatment of the Cells with the Specific Proteasome Inhibitor MG-132 (5 $\mu$ M for $2 \mathrm{~h}$ )

\begin{tabular}{|c|c|c|c|c|c|c|}
\hline$n=4$ & $\begin{array}{c}\text { Arginine } \\
\text { (nmol/mg protein) }\end{array}$ & $\begin{array}{c}\text { ADMA } \\
\text { (nmol/mg protein) }\end{array}$ & $\begin{array}{c}\text { SDMA } \\
\text { (nmol/mg protein) }\end{array}$ & $\begin{array}{l}\text { Arginine/ } \\
\text { ADMA }\end{array}$ & $\begin{array}{l}\text { Arginine/ } \\
\text { SDMA }\end{array}$ & $\begin{array}{l}\text { ADMA/ } \\
\text { SDMA }\end{array}$ \\
\hline $\begin{array}{l}\text { Hydrolysates } \\
\text { A549 }\end{array}$ & $47.3 \pm 5.6$ & $0.41 \pm 0.12$ & $0.11 \pm 0.01$ & $\begin{array}{c}131 \pm 49 \\
(0.8 \%)\end{array}$ & $\begin{array}{c}448 \pm 97 \\
(0.2 \%)\end{array}$ & $3.9 \pm 1.1$ \\
\hline $\begin{array}{l}\text { Hydrolysates } \\
\text { A549 + MG-132 }\end{array}$ & $58.2 \pm 3.7$ & $0.22 \pm 0.05$ & $0.10 \pm 0.01$ & $\begin{array}{c}280 \pm 57 \\
(0.4 \%)\end{array}$ & $\begin{array}{c}594 \pm 52 \\
(0.2 \%)\end{array}$ & $2.2 \pm 0.3$ \\
\hline $\begin{array}{l}\text { Crude Extracts } \\
\text { A549 }\end{array}$ & $4.14 \pm 0.4$ & $0.022 \pm 0.003$ & $0.010 \pm 0.002$ & $\begin{array}{l}190 \pm 5 \\
(0.5 \%)\end{array}$ & $\begin{array}{c}421 \pm 103 \\
(0.2 \%)\end{array}$ & $2.2 \pm 0.5$ \\
\hline
\end{tabular}

Table 2. Comparison of the Degree of Arginine Methylation in Heart and Kidney Protein Hydrolysates and Their Respective Crude Extracts

\begin{tabular}{|c|c|c|c|c|c|c|}
\hline$n=6$ & $\begin{array}{c}\text { Arginine } \\
\text { (nmol/mg protein) }\end{array}$ & $\begin{array}{c}\text { ADMA } \\
\text { (nmol/mg protein) }\end{array}$ & $\begin{array}{c}\text { SDMA } \\
\text { (nmol/mg protein) }\end{array}$ & $\begin{array}{l}\text { Arginine/ } \\
\text { ADMA }\end{array}$ & $\begin{array}{l}\text { Arginine/ } \\
\text { SDMA }\end{array}$ & $\begin{array}{l}\text { ADMA/ } \\
\text { SDMA }\end{array}$ \\
\hline $\begin{array}{l}\text { Hydrolysates } \\
\text { Heart }\end{array}$ & $160.6 \pm 51.4$ & $1.11 \pm 0.53$ & $0.22 \pm 0.07$ & $\begin{array}{c}165 \pm 65 \\
(0.6 \%)\end{array}$ & $\begin{array}{c}811 \pm 383 \\
(0.1 \%)\end{array}$ & $5.0 \pm 1.4$ \\
\hline $\begin{array}{l}\text { Hydrolysates } \\
\text { Kidney }\end{array}$ & $278.4 \pm 141.2$ & $1.41 \pm 0.26$ & $0.27 \pm 0.03$ & $\begin{array}{c}200 \pm 105 \\
(0.5 \%)\end{array}$ & $\begin{array}{c}1008 \pm 484 \\
(0.1 \%)\end{array}$ & $5.1 \pm 0.5$ \\
\hline $\begin{array}{l}\text { Crude Extracts } \\
\text { Heart }\end{array}$ & $2.13 \pm 0.4$ & $0.014 \pm 0.004$ & $0.0026 \pm 0.0005$ & $\begin{array}{c}169 \pm 57 \\
(0.6 \%)\end{array}$ & $\begin{array}{c}825 \pm 60 \\
(0.1 \%)\end{array}$ & $5.3 \pm 1.5$ \\
\hline $\begin{array}{l}\text { Crude Extracts } \\
\text { Kidney }\end{array}$ & $7.59 \pm 3.2$ & $0.037 \pm 0.014$ & $0.033 \pm 0.012$ & $\begin{array}{c}207 \pm 68 \\
(0.5 \%)\end{array}$ & $\begin{array}{c}232 \pm 66 \\
(0.4 \%)\end{array}$ & $1.2 \pm 0.5$ \\
\hline
\end{tabular}


In order to show that the described method is suitable for monitoring dynamic changes in arginine methylation patterns in biologically relevant samples, we assessed A549 epithelial cells under different cell culture conditions. Specifically, we reasoned that protein degradation has a significant impact on the amount of methylated arginines and quantified arginine methylation in A549 cells in the absence or presence of the proteasome inhibitor MG-132. As depicted in Table 1, inhibition of the proteasome led to an expected increase of L-Arg levels in protein hydrolysates (58.2 \pm $3.7 \mathrm{nnmol} / \mathrm{mg}$ protein versus $47.3 \pm$ $5.6 \mathrm{nmol} / \mathrm{mg}$ protein; $P<0.05)$ with a concomitant decrease of free L-Arg levels $(3.01 \pm 0.3 \mathrm{nnmol} / \mathrm{mg}$ protein versus $4.14 \pm 0.4 \mathrm{nmol} / \mathrm{mg}$ protein; $P$ $<0.05$ ), suggesting decreased protein breakdown. Interestingly, we observed a strong reduction in free ADMA $(0.015 \pm 0.002 \mathrm{nnmol} / \mathrm{mg}$ protein versus $0.022 \pm 0.003 \mathrm{nmol} / \mathrm{mg}$ protein; $P<0.05)$ but also in protein-incorporated ADMA levels $(0.22 \pm 0.05$ $\mathrm{nnmol} / \mathrm{mg}$ protein versus $0.41 \pm 0.12$ $\mathrm{nmol} / \mathrm{mg}$ protein; $P<0.05)$ after MG132 treatment, while SDMA levels in the same samples did not change (Table 1). This led to selective changes in the arginine/ADMA, arginine/SDMA, and ADMA/SDMA ratios of proteinincorporated methylarginine (Table 1). Therefore, these data suggest that the application of the proteasome inhibitor results in the specific inhibition of type I PRMT activity without affecting type II PRMT activity. Current and future work will therefore strive to understand the mechanisms that regulate PRMT activity via the proteasome pathway.

\section{Quantification of Protein Arginine Methylation in the Heart and Kidney}

We then sought to test our method on an in vivo scenario and asked whether different organs exhibited distinct methylation characteristics. As such, we measured the concentrations of methylarginines in tissue lysates derived from mouse heart and kidney homogenates. As depicted in Table 2 , we detected different methylation patterns in heart and kidney lysates. We found that $0.5 \%-0.6 \%$ of all arginine residues in heart and kidney protein hydrolysates were asymmetrically dimethylated, while symmetric dimethylation occurred in approximately $0.1 \%$ (Table 2). We were unable to detect any degree of monomethylation of arginine residues in either hydrolysates. Crude kidney extracts exhibited a significant higher level of free ADMA and SDMA $(0.037 \pm 0.014 \mathrm{nmol} / \mathrm{mg}$ protein, $P$ $<0.05$, and $0.033 \pm 0.012 \mathrm{nmol} / \mathrm{mg}$ protein, $P<0.001$, respectively), supporting the idea that the kidneys provide the main route for clearance of ADMA and SDMA (13). Furthermore, we observed a comparable degree of arginine methylation in free and incorporated amino acids in mouse heart (Table 2). Since a de novo synthesis pathway of ADMA or SDMA from free L-Arg has not been documented, we thus speculate that free methylarginines in the heart are derived from protein turnover and degradation of proteins containing methylarginines.

In conclusion, we present a novel method for the accurate quantification of arginine methylation in vitro and in vivo, using cell culture lysates and tissue homogenates. This method is suitable for the determination of arginine methylation in different tissues (and, by extension, in similar tissues in healthy and diseased states) and for the analysis of changes in arginine methylation in cell cultures exposed to stimuli that modify arginine methylation. In conjunction with the expression and activity analysis of PRMTs and dimethylarginine dimethylaminohydrolases (DDAHs), this method will lead to the identification of stimuli that modify arginine methylation and the disease states that coincide with the changes in arginine methylation.

\section{COMPETING INTERESTS STATEMENT}

The authors declare no competing interests.

\section{REFERENCES}

1. Vallance, P., A. Leone, A. Calver, J. Collier, and S. Moncada. 1992. Accumulation of an endogenous inhibitor of nitric oxide synthesis in chronic renal failure. Lancet 339:572-575.

2. McDermott, J.R. 1976. Studies on the catabolism of Ng-methylarginine, $\mathrm{Ng}, \mathrm{Ng}$-dimethylarginine and $\mathrm{Ng}$, Ng-dimethylarginine in the rabbit. Biochem. J. 154:179-184.

3. Cooke, J.P. 2000. Does ADMA cause endothelial dysfunction? Arterioscler. Thromb. Vasc. Biol. 20:2032-2037.

4. MacAllister, R.J., G.S. Whitley, and P. Vallance. 1994. Effects of guanidino and uremic compounds on nitric oxide pathways. Kidney Int. 45:737-742.

5. Boger, R.H., S.M. Bode-Boger, A. Szuba, P.S. Tsao, J.R. Chan, O. Tangphao, T.F. Blaschke, and J.P. Cooke. 1998. Asymmetric dimethylarginine (ADMA): a novel risk factor for endothelial dysfunction: its role in hypercholesterolemia. Circulation 98:1842-1847.

6. Miyazaki, H., H. Matsuoka, J.P. Cooke, M. Usui, S. Ueda, S. Okuda, and T. Imaizumi. 1999. Endogenous nitric oxide synthase inhibitor: a novel marker of atherosclerosis. Circulation 99:1141-1146.

7.Zoccali, C., S. Bode-Boger, F. Mallamaci, F. Benedetto, G. Tripepi, L. Malatino, A. Cataliotti, I. Bellanuova, et al. 2001. Plasma concentration of asymmetrical dimethylarginine and mortality in patients with end-stage renal disease: a prospective study. Lancet 358:2113-2117.

8. Clarke, S. 1993. Protein methylation. Curr. Opin. Cell Biol. 5:977-983.

9. McBride, A.E. and P.A. Silver. 2001. State of the arg: protein methylation at arginine comes of age. Cell 106:5-8.

10. Boisvert, F.M., J. Cote, M.C. Boulanger, and S. Richard. 2003. A proteomic analysis of arginine-methylated protein complexes. Mol. Cell. Proteomics 2:1319-1330.

11. Ong, S.E., G. Mittler, and M. Mann. 2004 Identifying and quantifying in vivo methylation sites by heavy methyl SILAC. Nat. Methods 1:119-126.

12. Boger, R.H., K. Sydow, J. Borlak, T. Thum, H. Lenzen, B. Schubert, D. Tsikas, and S.M. Bode-Boger. 2000. LDL cholesterol upregulates synthesis of asymmetrical dimethylarginine in human endothelial cells: involvement of S-adenosylmethioninedependent methyltransferases. Circ. Res. 87:99-105.

13. Vallance, P. and J. Leiper. 2004 Cardiovascular biology of the asymmetric dimethylarginine:dimethylarginine dimethylaminohydrolase pathway. Arterioscler. Thromb. Vasc. Biol. 24:1023-1030.

14. Teerlink, T. 1994. Derivatization of posttranslationally modified amino acids. J. Chromatogr. B Biomed. Appl. 659:185-207.

15. Pettersson, A., L. Uggla, and V. Backman. 1997. Determination of dimethylated arginines in human plasma by high-performance liquid chromatography. J. Chromatogr. B Biomed. Sci. Appl. 692:257-262.

16. Pi, J., Y. Kumagai, G. Sun, and N. Shimojo. 2000. Improved method for simultaneous determination of L-arginine and its monoand dimethylated metabolites in biological samples by high-performance liquid chromatography. J. Chromatogr. B Biomed. Sci. Appl. 742:199-203. 
17. Teerlink, T., R.J. Nijveldt, S. de Jong, and P.A. van Leeuwen. 2002. Determination of arginine, asymmetric dimethylarginine, and symmetric dimethylarginine in human plasma and other biological samples by highperformance liquid chromatography. Anal. Biochem. 303:131-137.

18. Heresztyn, T., M.I. Worthley, and J.D. Horowitz. 2004. Determination of L-arginine and NG, NG - and NG, NG' -dimethyl- L-arginine in plasma by liquid chromatography as AccQ-Fluor fluorescent derivatives. J. Chromatogr. B Analyt. Technol. Biomed. Life Sci. 805:325-329.

19. Unceta, N., A.S. Vicente, M.A. Goicolea, J. Salles, and R.J. Barrio. 2002. Determination of methylarginines in human plasma by HPLC with pre-column derivatization using napthalenedicarboxaldehyde as fluorogenic agent. J. Sep. Sci. 25:665-670.

20. Nonaka, S., M. Tsunoda, K. Imai, and T. Funatsu. 2005. High-performance liquid chromatographic assay of $\mathrm{N}(\mathrm{G})$-monomethyl- L-arginine, N(G),N(G)-dimethyl- L-arginine, and $\mathrm{N}(\mathrm{G}), \mathrm{N}(\mathrm{G})^{\prime}$-dimethyl- L-arginine using 4-fluoro-7-nitro-2, 1,3-benzoxadiazole as a fluorescent reagent. J. Chromatogr. A. 1066:41-45.

21. Causse, E., N. Siri, J.F. Arnal, C. Bayle, P. Malatray, P. Valdiguie, R. Salvayre, and F. Couderc. 2000. Determination of asymmetrical dimethylarginine by capillary electrophoresis-laser-induced fluorescence. J. Chromatogr. B Biomed. Sci. Appl. 741:77-83.

22. Vishwanathan, K., R.L. Tackett, J.T. Stewart, and M.G. Bartlett. 2000. Determination of arginine and methylated arginines in human plasma by liquid chromatography-tandem mass spectrometry. J. Chromatogr. B Biomed. Sci. Appl. 748:157-166.

23. Huang, L.F., F.Q. Guo, Y.Z. Liang, B.Y. Li, and B.M. Cheng. 2004. Simultaneous determination of L-arginine and its mono- and dimethylated metabolites in human plasma by high-performance liquid chromatographymass spectrometry. Anal. Bioanal. Chem. 380:643-649.

24. Pawlak, M.R., C.A. Scherer, J. Chen, M.J. Roshon, and H.E. Ruley. 2000. Arginine Nmethyltransferase 1 is required for early postimplantation mouse development, but cells deficient in the enzyme are viable. Mol. Cell. Biol. 20:4859-4869.

25.Deibler, G.E. and R.E. Martenson. 1973. Determination of methylated basic amino acids with the amino acid analyzer. Application to total acid hydrolyzates of myelin basic proteins. J. Biol. Chem. 248:2387-2391.

Received 18 May 2005; accepted 20 October 2005.

Address correspondence to: Patrick Bulau, University of Giessen Lung Center, University of Giessen School of Medicine, Aulweg 123, D-35329 Giessen, Germany. e-mail: Patrick.Bulau@innere.med.uni-giessen.de
To purchase reprints

of this article, contact

Reprints@BioTechniques.com 